Published as: De Coene, K., Ongena, T., Stragier, F., Vervust, S., Bracke, W. \& De Maeyer, P. (2012). Ferraris, the legend. The Cartographic Journal, vol. 49 (1), pp. 30-42.

\title{
FERRARIS, THE LEGEND
}

\author{
Karen De Coene, Thérèse Ongena ${ }^{1}$, Frederic Stragier, Soetkin Vervust, Wouter Bracke, Philippe De \\ Maeyer \\ Department of Geography, Ghent University, Gent, Belgium \\ Email: Karen.DeCoene@UGent.be \\ Therese.Ongena@UGent.be \\ Frederic.Stragier@ua.ac.be (Department of Biology, Ecosystem Management Research Group, \\ University of Antwerp) \\ Soetkin.Vervust@UGent.be \\ Wouter.Bracke@kbr.be (Prints and Maps, Royal Library of Belgium) \\ Philippe.DeMaeyer@UGent.be
}

\section{ABSTRACT}

At the end of the 18th century, a large-scale map of the Austrian Netherlands and the Prince-Bishopric of Liège was manufactured, covering more or less the current territory of Belgium. The work for this Carte de Cabinet was carried out by artillerists under the guidance of count Joseph de Ferraris, who was commissioned for the task by the Habsburg government. At the time that the map was designed, no modern legend was included. This report tries to fill that gap by presenting a legend that was constructed more systematically than any of its predecessors. It is based on the structure of the legend of the Topographic Map of Belgium and the CORINE land cover map, making it an easy-to-use tool for modern researchers. The problems encountered during the development of the legend are described, and the link between the Carte de Cabinet and $18^{\text {th }}$-century French cartography as well as with cartographic manuals is also discussed.

\section{INTRODUCTION}

In the last quarter of the eighteenth century, an important chapter in Belgian map making was about to be written. For the first time, a territory was going to be mapped in a detailed, systematic and complete way. Count de Ferraris was commissioned by the Habsburg government to make a large-scale map of the Austrian Netherlands and the Prince-Bishopric of Liège. As this map included almost the entire territory of Belgium today, it is perceived as the first topographic map of the country. For scientists and cartographers of the nineteenth and twentieth centuries, it served as a model for map making of the Belgian territory (De Maeyer, 2008). Since its creation, the Ferraris map has served as a protagonist in the history of cartography in the Belgian discourse.

\footnotetext{
${ }^{1} \mathrm{KDC}=\mathrm{TO}$
} 
There is, however, one gap in this Belgian cartographic saga: the Ferraris map, or the Carte de Cabinet des Pays-Bas autrichiens levée à l'initiative du comte de Ferraris, as it is officially known, lacks a comprehensive legend. To a modern cartographer, the absence of a legend that accompanies and explains the map might be surprising. After all, a map is a rhetorical operation and represents a graphic discourse. As such, the use of a legend is of crucial importance (Besse, 2008).

However, no legend was included in the eighteenth century Carte de Cabinet, which was a map that served a military purpose. The opposite is true for the Carte Marchande, a map that Ferraris derived from the Carte de Cabinet, but which was adapted for public sale. It was a reduced version of the original Carte de Cabinet on the same scale as the Carte de France made by the Cassini family $(1: 86,400)$ and did include a legend.

The real issue at stake related to the Carte de Cabinet is the definition of a legend. Cartographers currently understand a legend as the 'amplification or explanation of the symbols and conventions on a map' (ICA, 1973). It is difficult to find the word 'legend' on $18^{\text {th }}$ century maps. When Dupain de Montesson used this word in his cartographic manual from 1763, he stated that the marching order of the soldiers should be 'written in legend' to avoid confusion (Montesson, 1775, p. 184). In another handbook produced more than twenty years earlier, reference letters and figures are used to indicate fortifications, military buildings with provisions and equipment of the royal army on a map. They were relegated to a 'legend' on the side of the map (Buchotte, 1754). Map making in the $18^{\text {th }}$ century often (but not exclusively) served military purposes, and it is within this context that the word 'legend' acquired a cartographic definition for the first time. In the manuals of Lacroix and Marie from the beginning of the $19^{\text {th }}$ century, the word legend is used for cartographic semiotics. To Lacroix, the way to use a map is obvious. The symbols are easy to recognise, and if not, a legend can be placed on either side of the map (Lacroix, 1811, p. 165). In his manual, Marie repeats the same arguments: a legend prevents confusion and overcrowding. When colours are used, they can be represented in small blocks (Marie, 1825$, p. $4,12,46,53)$. With regard to the representation of colours in particular, Marie's approach indicates that we find here for the first time the modern legend as we define it today.

Although bearing a later date, the examples of Lacroix and Marie clearly indicate the difference in perception between modern day cartography and the $18^{\text {th }}$ century view. In the $18^{\text {th }}$ century, the legend was a tool that should only be used when the map was not satisfactory in showing as much information as possible in a clear way. Written or drawn information on a map was preferred to symbols. Therefore, an engineer learned a cartographic language at school that used evident, i.e., with obvious meaning for all users, and conventional, i.e., agreed upon, signs. Buchotte referred to this as 'observations où règles de convenance et des maximes pour la pratique du Dessin et du Lavis'. After an engineer started his career, manuals remained at his disposal. A good hand and a great deal of practice were prerequisites for both map makers and map users (Buchotte, 1754; Lacroix, 1811). Mémoires, i.e., written reports that accompanied the map, rendered final information. Thus, a survey of all symbols used was not deemed necessary. The semiotics used on Ferraris's map were meant to be easily readable. Many landscape elements were given a realistic representation that was entirely clear to a contemporary map user. When executed well, maps and plans were drawn with 'scrupulous exactitude' according to Dupain de Montesson (Dupain, 1775). Unfortunately, modern cartographers do not hold this opinion and consider old maps to lack standardisation.

For modern historical and geographical scholars, the Carte de Cabinet constitutes a primary source of information on the pre-industrial landscape; however, these researchers are not familiar with $18^{\text {th }}$ century cartographic semiotics. Thus, a (re)construction of the legend of the Carte de Cabinet might be very useful to these individuals.

Therefore, in this report, we will attempt to reconstruct the legend and elaborate on the relationship between the iconography of the Ferraris map and cartographic manuals, as well as its relationship with Cassini's Carte de France (1756-1789). In this way, we hope to somewhat clarify the dissemination of cartographic know-how in the eighteenth century and draw some preliminary conclusions about the level of accuracy of the Ferraris map. 


\section{THE LEGEND: HISTORICAL FACTS}

In spite of its name, the initiative for the Ferraris map did not come from Ferraris. During his lifetime, JosephJean-François de Ferraris was a protégé first of Léopold I, duc de Lorraine, and later of the Viennese court where he received his education. At an early age, he joined the army in an infantry regiment. From 1764 onwards (or perhaps earlier), Ferraris was stationed in the Austrian Netherlands. In 1767, he became head of the artillery there. Until 1768, Ferraris was not known as a cartographer, although cartography was part of his education, as it was for all artillerists (Lemoine-Isabeau, 1983, p. 240).

The decision to produce a map of the Austrian Netherlands was made by Empress Maria Theresia of Austria. During the Seven Years' War, from 1756 till 1763, inaccurate maps were partly responsible for Austrian military losses. Therefore, Maria Theresia planned a total Landesaufnahme, a survey of her territories, and in 1759, she asked for the support of Charles de Lorraine, governor of the Austrian Netherlands and her brother-in-law. ${ }^{1}$ It took until May $13^{\text {th }}$ of 1764 before the Austrian Hofkriegsrat was permitted to give the orders for the first Austrian survey on a scale of $1: 28,800$ (1 Wiener Zoll: 400 Wiener Klafter), starting in Böhmen and Mähren (Gachard, 1843, p. 4-5; Lemoine-Isabeau, 1983, p. 228).

Since the Treaty of Aix-la-Chapelle in 1748, which marked the end of the War of the Austrian Succession (17401748), Charles de Lorraine was the governor of the Austrian Netherlands, and he represented the archduchess until 1780. Due to the loss of Silesia to Frederick the Great during the war, Maria Theresia renounced the political tolerance that the Habsburg rulers maintained toward their territories and began to develop a strong central government. Initially, the economic prosperity and military security that Charles de Lorraine attempted to bring to the Austrian Netherlands were not hampered by this new policy. However, all of this changed with the arrival of Count Charles de Cobenzl, who was promoted to Minister Plenipotentiary of the Austrian Netherlands in 1753. His centralistic convictions did not coincide with Charles de Lorraine's political aspirations (Vann, 1992; Galand, 1993). It was therefore only shortly after Cobenzl's death in January 1770 that Charles de Lorraine could recommend Ferraris's project in Vienna. Maria Theresia agreed on the $11^{\text {th }}$ of August 1770 (Lemoine-Isabeau, 1983, p. 245; Galand, 1993, p. 149).

The people involved in the mapping of the Austrian Netherlands were often related to Charles de Lorraine. This certainly holds true for Ferraris himself. Charles had a major interest in cartography, and several military geographers were part of his entourage. Starting in 1756, the Kaiserliches und Königliches Niederländischen National Feld Artillerie Corps at Malines was reorganised in accordance with the artillery brigades of the Habsburg monarchy (Rooms, 1994, p. 859). It became a state-of-the-art artillery. In 1767, when Ferraris became its Director-General, 813 men made up the artillery corps in Malines. There was a staff of 18 men and 12 companies of 61 to 82 men. Cadets and officers were trained by Léopold François Cogeur, who taught mathematics at the artillery academy. He made maps of the Forêt de Soignes (1767-1770) and the domain of Mariemont (1769). The oldest professors at the artillery academy in Malines received their education in Brussels at the Académie militaire du Génie, which was established in 1753 by Nicolas Bernard de Hucher (Lemoine-Isabeau, 1984, p. 63).

A previous initiative of the French engineer Colonel Baron de Bon added greatly to Ferraris's project. De Bon was most likely delegated by the French to assist their Austrian ally during the Seven Years' War. His project of surveying the Netherlands was quite similar to the one that Ferraris would later undertake. As Baron de Bon became the French ambassador to Austria in 1769 (until 1774), his project, which had been rejected due to its expense, would be executed by Ferraris to a large extent (Gachard, 1843, p. 7). In a letter written on 18 September 1771, de Bon stated that it pleased him that Ferraris was following his methods and his principles. It is interesting to note how de Bon describes the situation in these terms, while in later history, the map was completely attributed to Ferraris. De Bon planned a double map: one in manuscript (1:14,400), to be preserved as a military document, and the other without military details, engraved on a smaller scale (1 : $86,400)$, to be sold to recoup the expense of producing the map. De Bon named the map of France by Cassini as 
both a source and an example. Ferraris maintained this double goal in the later Carte de Cabinet and Carte Marchande (Gachard, 1843; Lemoine-Isabeau, 1983, p. 229-230).

The differences between Ferraris's map and de Bon's proposal were merely a matter of scale, staff, cost and especially of tactics. The scale Ferraris proposed was $1: 11,520$ instead of $1: 14,400$. De Bon needed only 46 men, Ferraris 69. De Bon would have used staff officers during peacetime to keep them in good shape. Ferraris preferred artillerists and paid them a mere pittance instead of the high wages that staff officers earned. De Bon had estimated the costs at 183,000 German florins, which is the reason that his proposal was rejected. Ferraris mentioned only the starting expenses (12,000 German florins) and promised to invest a great deal of his own means. The low cost appeared to be a final argument resulting in the approval of the survey. It could be paid by the income from the Genoese lottery. Although the amount was far from realistic, this was a clever tactic on the part of Ferraris, as this limited initial funding would later be used as an argument for extra financial support. The final difference in the two proposals was related to the initiators themselves: De Bon remained French, while Ferraris followed the Duke of Lorraine and received his education at the Viennese court (Gachard, 1843, pp. 8-15; Lemoine-Isabeau, 1983, pp. 232-235).

As soon as he received authorisation, Ferraris initiated a test case in the Seigneurie de Malines, which was presented to governor Charles de Lorraine and to Empress Maria Theresia in February 1771 (Installé, 1997, p.202). Following this, between 1771 and 1774, the manuscript map of the entire territory was drawn up in three copies on a scale of $1: 11,520$. At first, only two copies were foreseen: one for Empress Maria Theresia (now: The Hague, Nationaal Archief) and one for Charles de Lorraine (now: Brussels, Koninklijke Bibliotheek van België). It was eventually decided to revise and improve upon the original sheets, which were drawn on plane tables in the field, and this version of the map served as a third copy for the Chancellery of Court and Nation in Vienna for the personal attention of Prince von Kaunitz. The map carries the name Carte de Cabinet, as it was reserved for imperial cabinet-use only and has many similarities to the Josephinische Landesaufnahme, which was the first extensive survey of the Habsburg territory. The name Carte Marchande, however, refers to the fact that this was a commercial map intended for sale to a larger audience.

\section{The Legend: BetWeEn JosephinISCHE LANDESAUfNAHME AND CASSINI'S}

\section{PUBLIC MAPS}

The Ferraris map was produced under a cartographic continuum between French and Austrian influences, characterising cartographic activities throughout northwestern Europe. Lemoine-Isabeau (1983, pp. 288-290) emphasised the difference in style and scale between the Ferraris map and Austrian cartography during the Josephinische Landesaufnahme. However, she convincingly argues that the map is related to French examples.

Historical arguments for this French influence are easy to make. First, the art of map making was mostly a French concern at the end of the seventeenth and in the eighteenth century. This tradition is due to the famous military engineer Vauban, who created a central service for map making, les Ingénieurs (géographes) des Camps et Armées, in 1696 and introduced the collaboration of surveyors (Cassini) and military engineers. By order of the top levels of military command, several French cartographic products related to the northern regions of the French territory were created. Within this framework, the cartographers Naudin ${ }^{2}$, Masse $^{3}$ and Pennier ${ }^{4}$ must be mentioned. Second, the project proposal for the Ferraris map was based on the work of the Frenchman Colonel Baron de Bon. Third, although the loyalty of the Lorrainers involved, such as Hucher and Cogeur, extended to the Habsburg monarchy, they were familiar with French cartography and had possibly obtained their education in France, or still had contacts with people from Lorraine who sought their refuge in

France. ${ }^{5}$ Fourth, Ferraris requested access to the French maps of the territory (Gachard, 1843, pp. 8-12; Lemoine-Isabeau, 1983, p.240). Furthermore, in the Mercure de France of 1777, the Carte Marchande of Ferraris was promoted by stating how Cassini had influenced it (Mercure de France, 1777, pp. 176-177). 
The Cassini map of France (1756-1789) was the model for eighteenth-century surveying projects throughout Europe, as it was for Ferraris. All of this did not accord with the principles of the Habsburg cartographic initiative. There was a major difference between French map making intentions and the ambitions of the Josephinische Landesaufnahme. The Cassini maps were a project funded by the state, but since its privatisation in 1756, they were also intended for a map-reading public, while the Habsburg surveys remained a closely guarded secret (Biggs, 1999, p. 384; Lemoine-Isabeau, 1983, p. 205-206; Pelletier, 1990, p. 117, Vann, 1992, pp. 163-164). Despite these different intentions, Charles de Lorraine received permission during his audience with Maria Theresia in August 1770 for the sale of the Carte Marchande for the Austrian Netherlands (Gachard, 1843, p. 13). This again makes it clear that Charles de Lorraine was allowed to maintain some autonomy, which was probably due to the fact that the Austrian monarchs were his relatives. Despite the similar cartographic semiotics, the model of Cassini does not provide any solution concerning the legend because there is also no comprehensive legend available for this map.

At the time when Ferraris's Carte de Cabinet was produced, the need for a legend was simply not taken for granted. In the case of Ferraris, there is a written key included in the introduction of Ferraris's Mémoires, which accompany the Carte de Cabinet (Eclaircissement) (De Smet, 1965, p.35-36). However, as this is only a text key without visual representation, it is highly inadequate for the purposes of a present day cartographer. A depicted key was not at the map user's disposal in the $18^{\text {th }}$ century. Ferraris himself makes clear why. He stated that: 'Concerning the representation on the map of the objects in the field, the usual process is maintained' (De Smet, 1965, p.35-36).

What exactly determines this 'usual process' can be explained by the cartographic courses taught at the military school and the manuals at the disposal of the military. Cartographic semiotics were a part of the educational tools that the, often military, map user received. Students at the artillery school learned to translate the landscape into a cartographic script. Only a unified method distributed through education could make an elaborate legend superfluous, and such a method existed in France. Since 1720, the French king had created schools to prepare officers for the Corps d'artillerie. Between 1749 and 1752, the reference manual was the Cours de mathématiques, which was based upon lessons that Abbé Camus had given to the architecture students. Other manuals that were available for these courses included Buchotte's Les règles du dessin et du lavis (1754), and at the end of the century, Etienne Bézout's Cours de mathématiques à l'usage du corps royal de l'artillerie (1770-1782) (Halleux, Opsomer \& Vandersmissen, 1998, p. 400). To cite only one example, Bezout's work was used in the mathematics courses given by Dupont in January 1772 (Mercure de France, 1772, p. 188). In their Encyclopédie, Diderot and d'Alembert also describe how cartography formed a part of the education of the artillerists (Diderot \& d'Alembert, 1779, vol. 3 p. 558). Daniel-Charles Trudaine established a Bureau de dessinateurs in 1744 specifically for the purpose of map making, which comprised of a drafting room where the maps would be made. In 1747, the first head of the office was Jean-Rodolphe Perronet, who transformed the work of the drafting office into a training project for engineers (Konvitz, 1982, 1987).

Unfortunately, it is unknown which literature was used for the courses at the artillery school in Malines. However, de Bon wrote that the artillery students were disposed of enough know-how to carry out the survey, and being a Frenchman, he took the French example as a standard (Gachard, 1843). One can only assume that French manuals, such as Buchotte's Les règles du dessin et du lavis (1754), might have also been used in Malines. There seem to be similarities between the symbols in the manual of Buchotte and those used on the map of Ferraris, but unfortunately, Buchotte's manual mostly only describes these symbols, instead of presenting them as drawings. The same approach can be found in the written key included in the introduction of Ferraris's Mémoires. It is highly questionable whether any information on the subject is still preserved in archives, but an exhaustive comparative study between the cartographic manuals and Ferraris's map will shed light on this matter in future research by our group. For now, a short comparison, mainly with Buchotte's rules, indicates major differences between $18^{\text {th }}$ century and contemporary cartographic concepts. Because of the 
very specific meaning of the word 'legend' in the $18^{\text {th }}$ century, listing only the reference letters and figures that indicate a military presence, it is only a formal predecessor of our current understanding of what a legend is. The meaning of current legends is more comprehensive, although $18^{\text {th }}$ century engineers did have a similar conceptual framework for their map making. Their 'legend' consisted of the cartographic language in which they were educated, the written text that was presented on the map and the supplementary information provided in Mémoires.

The cartographic symbols used in the $18^{\text {th }}$ century were either self-evident or conventional. For instance, gallows should be drawn as they were in reality, 'just as they are' to put it in Buchotte's own words. However, a conventional style was used to render land covering. Land and forest are so common on maps that an easy style for representing them is necessary. A fast and efficient method is a necessary condition in this case. Additionally, although colours played a symbolic role, they could also be used to brighten up a map, such as when the aim was to represent arable land (Buchotte 1754, Lacroix 1811).

When we compare these 'maxims' for map making from the manual of Buchotte with the legend we reconstructed, there are striking differences. First, an alphabetic list is provided to the reader instead of a structured one. Second, military terminology, such as for the different kinds of batteries (batterie à barbette, batterie avec embrasures, caponnière), embrasures or glacis, played a key role in $18^{\text {th }}$ century mapping education. The choice to indicate a building on a map is often made on military grounds. For instance, a bakery may be located under a bastion and refers to the bread supply of the army. Once again, this illustrates the military basis of topographic cartography. Third, the symbols on Ferraris's map are never completely equal to the descriptions of Buchotte. A ferry on the Ferraris map does not show the associated fairway, although this is outlined in Buchotte's manual. Additionally, according to the book, structures such as chapels or barracks should be drawn only as buildings, without the further differences Ferraris describes. Furthermore, manuals were not always followed with the same rigor. Buchotte made a clear statement related to this matter: when drawing an unpaved road, certain draughtsmen used two parallel lines and added shadow at one side; Buchotte considered this as a sign of bad taste, as this style has no natural characteristics, and map users could misinterpret it as an aqueduct or a subterranean road (Buchotte, 1754). Notwithstanding of this critique, Ferraris's method for representing unpaved roads falls under the disapproved description.

\section{THE LEGEND: THE UPSHOT OF A CARTOGRAPHICAL PROCESS}

Producing a legend for the Ferraris map is fraught with numerous difficulties and requires making many generalisations, mainly because $18^{\text {th }}$ century cartographic script was not as standardised as a present-day cartographer would expect. To an $18^{\text {th }}$ century reader, it appeared that Ferraris's maps were the result of a survey conducted with great care and precision (Mercure de France, 1777, pp. 176-177). However, this is just not how we would perceive them today. The most obvious way that this can be illustrated is by comparing the three copies of the Carte de Cabinet (Moors, 2002). On the map of Prince von Kaunitz, the drawing grid is still clearly visible. Bushes, woodlands and gardens are almost never coloured nor filled with the required symbols. Most of the time, only a letter indicates the type of land cover (Bracke, 2009, p. 15). For example, a ' $p$ ' stands for 'prez' (pasture), while a 'b' means 'bois' (forest) (Malines, sheet 91; Zemst, sheet 92; Louvain, sheet 111). Therefore, the surveyor in the field gave only an indication of the semiotics on his plane table, while it was the cartographer in his office who completed the map by extending the cartographic code. Not one, but several cartographers continued the work, and each of them had an individual style. Differences in style were mentioned by Buchotte and are easy to demonstrate in, for instance, the reproduction of the mills on sheet 34 of the copy of Charles de Lorraine (Figure 1). The 97 to 178 surveyors involved in producing the map also each 
had an individual way of sketching on their plane tables. Additionally, the level of detail decreased as more sheets were finished. The first drawn sheet (that of Malines) ended up being the most finely detailed.

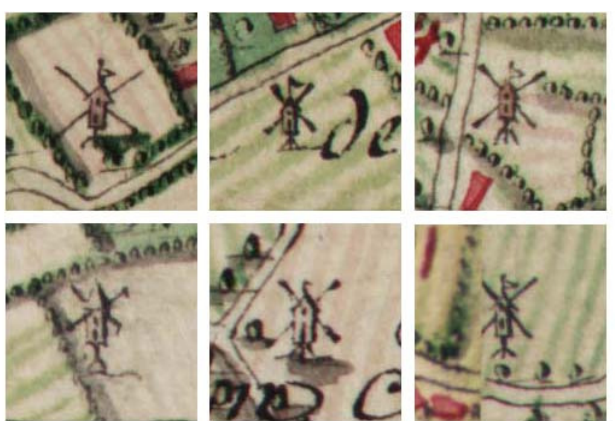

Figure 1. Some examples of wooden windmills represented by various symbols, as found on sheet 34 .

However, one must bear in mind that actual differences were also depicted on the map, so not everything can be attributed to stylistic variation, but while studying the symbols, it can be difficult to distinguish one from the other. An easy example of an actual difference is the representation of a stone mill, which is clearly different from the representation of a wooden mill (Figure 2). This distinction between building materials is mentioned by Ferraris in the introduction of his Mémoires (De Smet, 1965). Actually, it was quite a common rule to represent all stone elements in red, while wood was rendered in Indian ink (Buchotte, 1754)

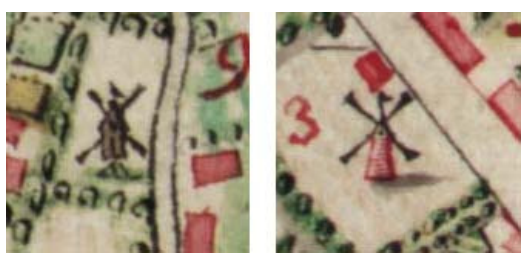

Figure 2. Symbols for a wooden mill and a stone mill, as found on sheet 34 .

Colour is another subject that requires discussion because it is extremely important for border representation. Every sheet has a slightly different use of colour. When colours are laid on top of each other in representations of a geographic relief or of borders, it can be difficult to identify them because the second coat was often applied when the first had not yet dried, and the paints have since merged. The use of inconsistent dilutions of colouring agents is probably also a reason for variation in colour. Finally, one has to bear in mind that colours on the map may have changed over time. The correlation between colours and borders, in particular, will be the next topic of our research.

An $18^{\text {th }}$ century geographer produced maps to the best of his abilities. The map user was fully aware of this when consulting a map. Small types of semiotic variations were not confusing due to the fact that the symbols were easily readable. For example, a church was drawn as a little church; a wood was filled with trees; and bridges and windmills were drawn differently depending on the building material used. What most concerned Ferraris's contemporaries was a correct representation of borders. The feudal chaos that characterised the frontiers in Ferraris's time was so complex that artillerists made mistakes and considered parts of free states, such as Liège or Stavelot, to be Austrian territories. Through the courtesy of the prince bishop of Liège, the prince abbot of Stavelot and the rulers of the many free states, a rectification of the border sections of the map was carried out between 1777 and 1779. The Carte de Cabinet often shows a double pattern in the border symbols because the borders were corrected later. It is revealing that the Carte Marchande, which was intended for the general public, shows a course in favour of the Austrian Empress, while the Carte de Cabinet 
provides a more elaborate view of this complex border situation. Researchers who are interested in these borders can consult the maps on which the rectification was recorded in Dubois (2001, p. XII, XV, XXIX-XXXI) for detailed information.

Therefore, the author producing a present-day legend for this map is confronted with a large number of both self-evident and conventional symbols that are not always equally standardised. This inevitably creates doubt about whether a certain symbol must be entered in the legend or whether it does not represent the tenor of the map and is only superfluous.

Several attempts to create a legend for the Ferraris map were published in the past, but none of them were based on a systematic analysis of the original map, and none of them have a clear structure (Kabinetskaart van de Oostenrijkse Nederlanden, 1965; Beyaert et al., 2006; De grote atlas van Ferraris, 2009). During the construction of the current legend, a systematic approach was kept in mind by analysing at least one quarter of every sheet of the copy of Charles de Lorraine. All three legends that were produced in the past are based on this copy, which made comparison easier. Furthermore, because it is the only copy of the Carte de Cabinet that is available on-line, it is the one that is most frequently used in modern research.

The resulting legend adds some new symbols compared to other currently available legends. The meaning of these new additions was derived by simple visual interpretation, or with the help of text occurring on the map. However, some symbols present in the previous legends were omitted from this one. This was done if the use of a certain symbol was not consistent throughout the map, so that its entry in the legend would only create ambiguity. Another reason for omission was that certain symbols were simply a combination of other symbols already present in the legend. Because the inclusion of these combined symbols added no new information, the choice was made to not insert them in the legend. Examples of this are roads lined with trees and the gallows field shown in Figure 3 consisting of several torture wheels and gallows (Wollseifen, sheet 248). An abbey was also considered to be a symbol composed of several other symbols, namely those for a conurbation, a church and a vegetable garden. All three examples are present in the other existing legends, but not in this one. Exceptions were made for a row of trees, as this is a linear symbol that can be found in almost any legend, and for a line of crosses bordering a road because these constitute the Stations of the Cross and, thus, have a more intricate meaning than simply being a combination of individual symbols.

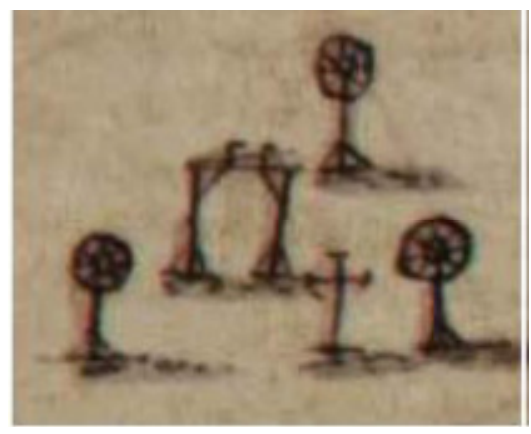

Figure 3. A gallows field

Furthermore, the distinction between the symbols in this legend is solely based upon colour and shape, not upon added text. Examples can be seen in Figure 4. An aqueduct that is represented by the symbol for a bridge, though defined in more detail by the word 'Aqueduc' (Peer, sheet 165), is not entered in the legend. The same convention was used for a remarkable tree specified by the word 'Le Tilleul' (Hoegaarden, sheet 112), 'the Lime Tree', and for the numerous buildings that are identified as a paper mill, a gin distillery, a forge, a foundry, a brickyard, a glassworks, a sawmill and a limekiln, among others. These are all simply classified as buildings. 

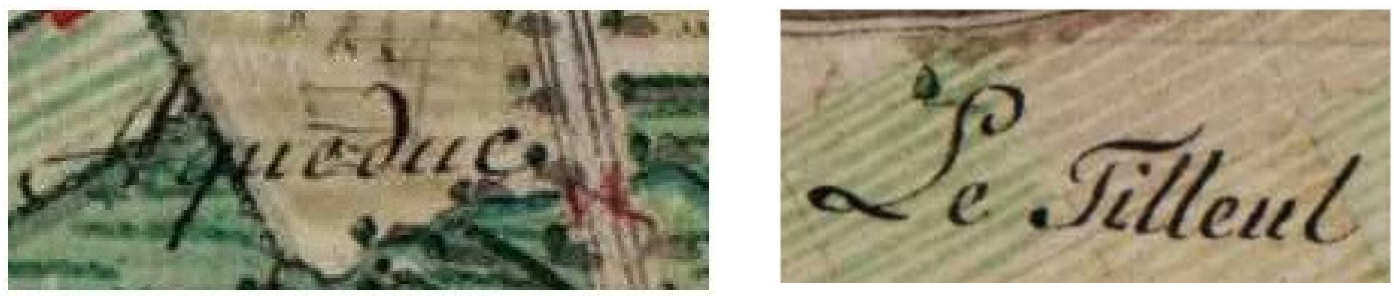

Figure 4. Examples of text giving additional information about the symbols on the map.

The above discussion clearly demonstrates that the aim of this legend was not to be as complete as possible but rather to create a general working instrument that was easy to use and not overly complicated due to containing too many symbols. Furthermore, for each symbol in the legend, only one typical example of its representation on the map was included, although variations in a given type of symbol could almost always be found. In an attempt to further increase its usability, the structure of the legend was also revised. The legends of the contemporary Topographic Map of Belgium (Nationaal Geografisch Instituut, 2006) and the CORINE Land Cover map (Commission of the European Communities, 1994) served as models for the structure of the legend presented here. This choice was made because a present-day map user will be familiar with this type of structure. However, one should still bear in mind that it is difficult to reconcile our demand for cartographic accuracy with the semiotics of Ferraris's maps. The legend we present here should, therefore, be used with caution, and its symbols should always be interpreted in the context of the map. Keeping in mind that $18^{\text {th }}$ century mapmakers each had their own legend consisting of their cartographical script, manuals and memoirs, the reconstructed legend reconciles this $18^{\text {th }}$ century mental legend with our present-day notion of the word.

\section{NOTES}

${ }^{1}$ The Duchy of Lorraine played a key role not only for the Austrian Netherlands but for the Habsburg dynasty as well. Charles de Lorraine was the brother of Duke Francis III (Stephan I). After the death of the last male of the Habsburg dynasty, Maria Theresia carried on the Habsburg tradition through her marriage with Francis. This was the foundation of the House of Habsburg-Lorraine. Because Lorraine became an Austrian enclave in French territory through the marriage, it was ceded to France in exchange for Tuscany. However, many of the noblemen of Lorraine followed the Duke to Vienna. When Charles de Lorraine married Marie-Anne, the youngest sister of Maria Theresia in 1744, the strong connection between Lorraine and Vienna was reestablished.

${ }^{2}$ Théâtre de la Guerre en Flandres $(1: 72.000)$ and Les Frontières du Nord et de l'Est $(1: 43.200)$

${ }^{3}$ La Frontière du Nord $(1: 28.800)$

${ }^{4}$ Camps et ordres de marches de l'armée du Roy, en Flandres, commandée par Monseigneur le maréchal duc de Luxembourg, sous Monseigneur, en l'année 1694: levez sur les lieux et dessinez par le Sr. Pennier geographe et ingénieur du Roy (1:72.000) and Les Cartes générales de Flandres ( $1: 43.200)$

${ }^{5}$ For instance, the Count of Choiseul, Minister of warfare (Lemoine-Isabeau, 1983, p.248).

\section{REFERENCES}

Besse, J.-M. (2008). 'Cartographie et pensée visuelle. Réflexions sur la schématisation graphique', in Les usages des cartes (XVIIe-XIXe siècle). Pour une approche pragmatique des productions cartographiques, ed. by Laboulais, I., pp.19-32, Presses Universitaires de Strassbourg, Strassbourg.

Beyaert, M., Antrop, M., De Maeyer, P., Vandermotten, C., Billen, C., Decroly, J.-M., Neuray, C., Ongena, T., Queriat, S., Van Den Steen, I., Wayens, B. (2006). België in kaart. De evolutie van het landschap in drie eeuwen cartografie, Lannoo, Tielt.

Bézout, E. (1770-1782). Cours de mathématique à l'usage du corps royal de l'artillerie, Ph.-D. Pierres, Paris. 
Biggs, M. (1999). 'Putting the State on the Map: Cartography, Territory, and European State Formation', Comparative Studies in Society and History, 41, pp. 374-405.

Bracke, W. (2009). 'De kaart van de Oostenrijkse Nederlanden door graaf de Ferraris', in De grote atlas van Ferraris, ed. N.N., pp. 5-19, Lannoo, Tielt.

Buchotte, M. (1754). Les règles du dessin et du lavis, L. Cellot, Paris.

Commission of the European Communities (1994). CORINE Land Cover, http://www.eea.europa.eu/publications/CORO-landcover.

Kabinetskaart van de Oostenrijkse Nederlanden, Ferrariskaart genoemd (1965), Koninklijke Bibliotheek van België en Gemeentekrediet van België Historische Uitgaven Pro Civitate reeks in- $4^{\circ}$ no.2, Brussel.

De grote atlas van Ferraris (2009). Lannoo, Tielt.

De Maeyer, P. (2008). Cartografie, Academia Press, Gent.

De Smet, A. (1965). 'Toelichting bij de Kabinetskaart van de Oostenrijkse Nederlanden', in Kabinetskaart van de Oostenrijkse Nederlanden. Inleiding, ed. N.N., pp. 35-36, Koninklijke Bibliotheek van België en Gemeentekrediet van België Historische Uitgaven Pro Civitate reeks in- $4^{\circ}$ no.2, Brussel.

De Smet, A. (1974). 'Le Général-Comte de Ferraris et la carte des Pays-Bas autrichiens, in Album Antoine De Smet, ed. N.N., pp. 347-362, Nationaal Centrum voor de Geschiedenis van de Wetenschappen, Brussel.

Diderot, D., d'Alembert, J.I.R. (1779). Encyclopédie ou Dictionnaire raisonné des sciences, des arts et des métiers / mis en ordre \& publié par $M$. Diderot, \& quant à la partie mathématique, par $M$. d'Alembert, Les Sociétés typographiques, Lausanne et Berne.

Dubois, S. (2001). La rectification du tracé des frontières sur les cartes des Pays-Bas autrichiens de Ferraris (1777-1779), Palais des Académies, Bruxelles.

Dupain de Montesson, M. (1763). L'art de lever les plans, Jombert, Paris.

Gachard, L. P. (1843). 'Notice historique sur la rédaction et la publication de la carte des Pays-Bas Autrichiens par le général comte de Ferraris', Nouveaux mémoires de I'Académie royale des sciences et de belles-lettres de Bruxelles, tome XVI, pp. 3-57.

Galand, M. (1993). Charles de Lorraine, gouverneur général des Pays-Bas autrichiens (1744-1780), Etudes sur le XVIIlè siècle vol. XX, Editions de I'Université de Bruxelles, Bruxelles.

Gautier, H. (1708). L'art de laver ou la nouvelle manière de peindre sur le papier, F. Foppens, Bruxelles.

Halleux, R., Opsomer, C., Vandersmissen, J. (eds.)(1998). Geschiedenis van de wetenschappen in België van de Oudheid tot 1815, Gemeentekrediet, Brussel.

Installé, H. (1997). Stedenatlas Mechelen. Deel 2, Koninklijke kring voor oudheidkunde, letteren en kunst van Mechelen, Mechelen.

International Cartographic Association (1973). Multilingual Dictionary of Technical Terms in Cartography, ed. by E. Meijnen, Franz Steiner Verlag, Wiesbaden.

Konvitz, J.W. (1982). 'Redating And Rethinking The Cassini Geodetic Surveys Of France, 1730-1750', Cartographica: The International Journal for Geographic Information and Geovisualization, 19, pp. 115.

Konvitz, J.W. (1987). Cartography in France, 1660-1848. Science, Engineering, and Statecraft, The University of Chicago Press, Chicago.

Lacroix, S.F. (1811). Introduction à la géographie mathématique et critique, Dentu, Paris (first edition 1804).

Lemoine-Isabeau, C. (1983). Genèse et étapes du levé topographique des Pays-Bas méridionaux et de la Principauté de Liège aux XVIle et XVIIle siècles, PhD thesis, Faculté de Philosophie et Lettres de I'Université Libre de Bruxelles, Bruxelles.

Lemoine-Isabeau, C. (1984). Les militaires et la cartographie des Pays-Bas méridionaux et de la Principauté de Liège à la fin du XVIle et au XVIIle siècle, Publications du Centre d'Histoire militaire no.19, Musée Royal de l'Armée, Bruxelles.

Marie, F.C.M. (1825). Principes du dessin et du lavis de la carte topographique, Bachelier, Paris.

Mercure de France par une société de gens de lettres. Janvier 1772, Premier Volume (1772). Lacombe, Paris.

Mercure de France par une société de gens de lettres. Octobre 1777, Premier Volume (1777). Marc-Michel Rey, Amsterdam.

Moors, R. (2002). Een vergelijking tussen verschillende exemplaren van de Kabinetskaart van de Oostenrijkse Nederlanden, thesis, Faculteit wetenschappen Departement geografie-geologie van de Katholieke Universiteit Leuven, Leuven.

Nationaal Geografisch Instituut (2006). Legende top 10-r en topografische kaart 1 : 10 000, http://www.ngi.be/Common/leg10/10000NL.htm. 
Pelletier, M. (1990). La carte de Cassini. L'extraordinaire aventure de la carte de France, Presses de l'école nationale des ponts et chaussées, Paris.

Rooms, E. (1994). 'Infanteriekorps(eerste helft 16de eeuw-1794)', in De Centrale Overheidsinstellingen van de Habsburgse Nederlanden, ed. by Aerts, E., Baelde, M., pp. 852-870, Algemeen Rijksarchief, Brussel.

Stragier, F. (2009). Kritische analyse van de legende van de Kabinetskaart van Ferraris, thesis, Faculteit wetenschappen Departement geografie van de Universiteit Gent, Gent.

Van Audenhove, M. (1978). 'Préface - Ten geleide', in De cartografie in de $18^{\mathrm{e}}$ eeuw en het werk van graaf de Ferraris (1726-1814). Handelingen, ed. N.N., pp. 7-10, Gemeentekrediet van België Historische Uitgaven Pro Civitate reeks in- $4^{\circ}$ no.54, Spa.

Vann, J. (1992). 'Mapping under the Austrian Habsburgs', in Monarchs, Ministers, and Maps: The Emergence of Cartography as a Tool of Government in Early Modern Europe, ed. by Buisseret, D., pp. 153-167 University of Chicago Press, Chicago. 

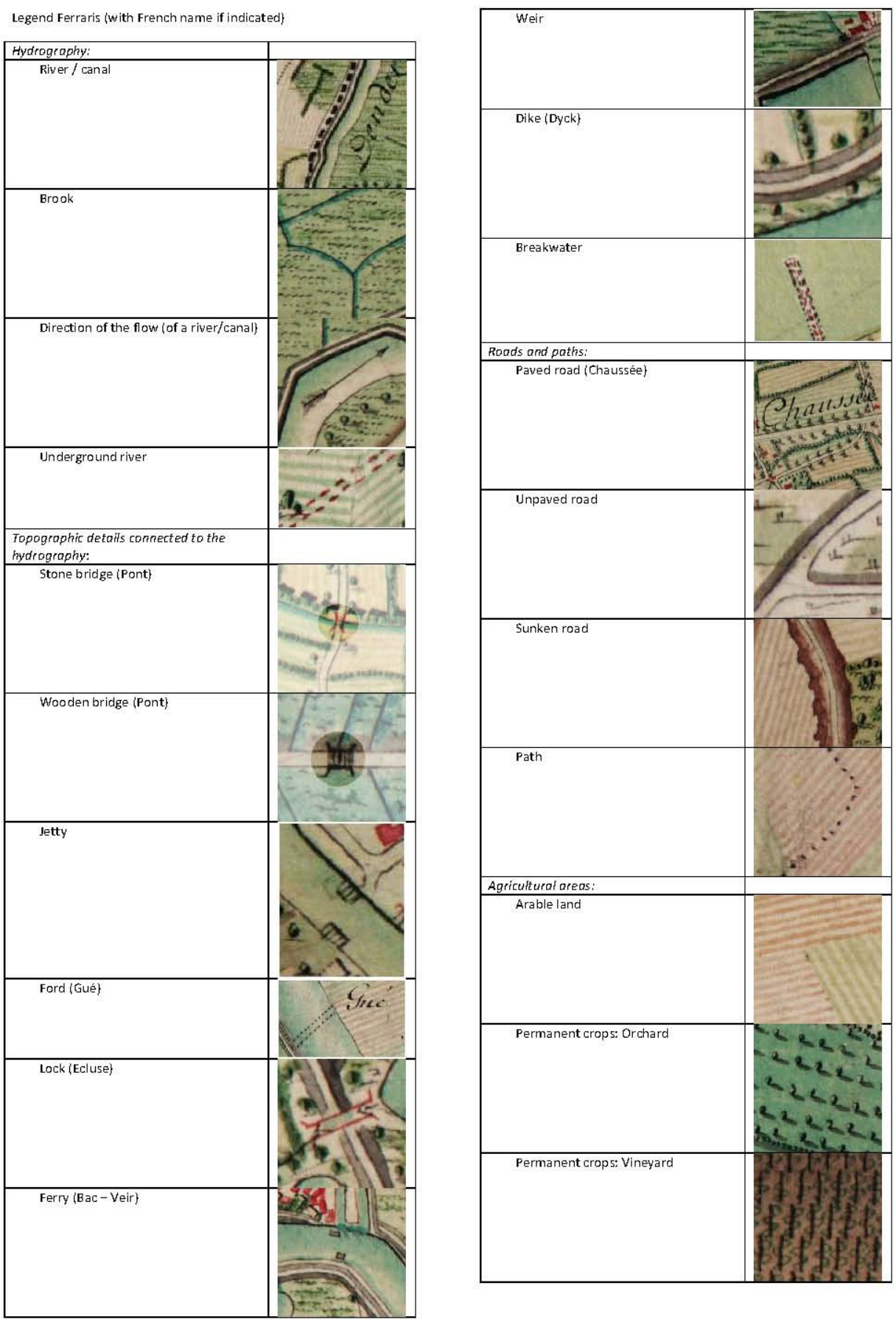


\begin{tabular}{|l|l|}
\hline Pastures & \\
\hline Vegetable garden & \\
\hline Pleasure garden - with semiotic \\
variety
\end{tabular}

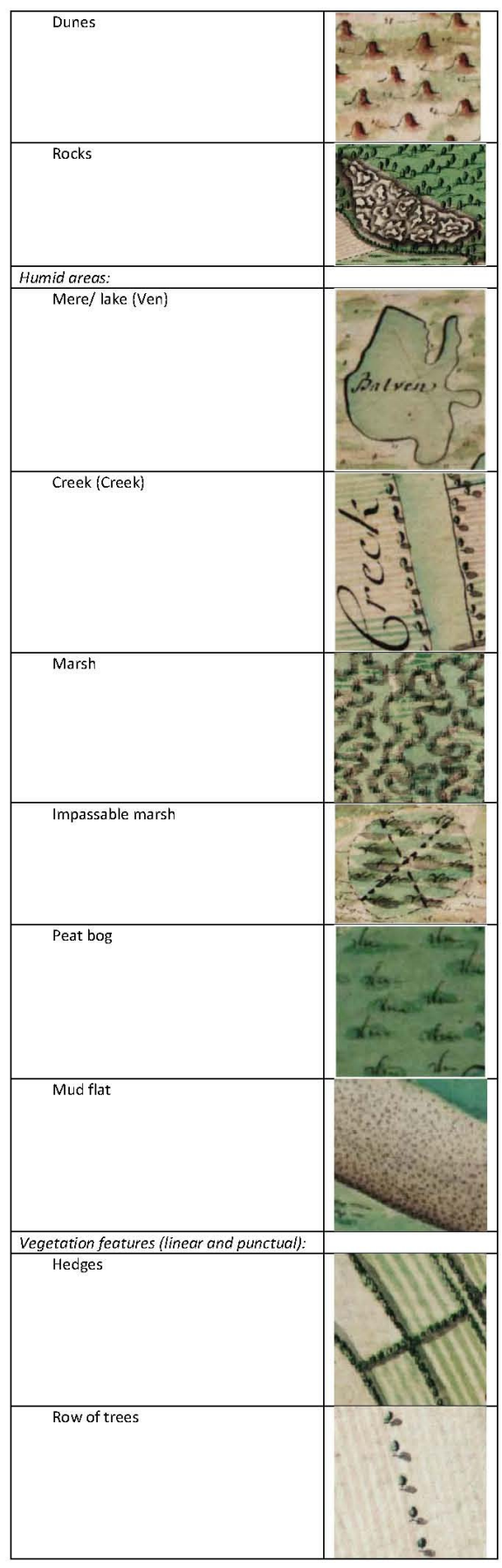



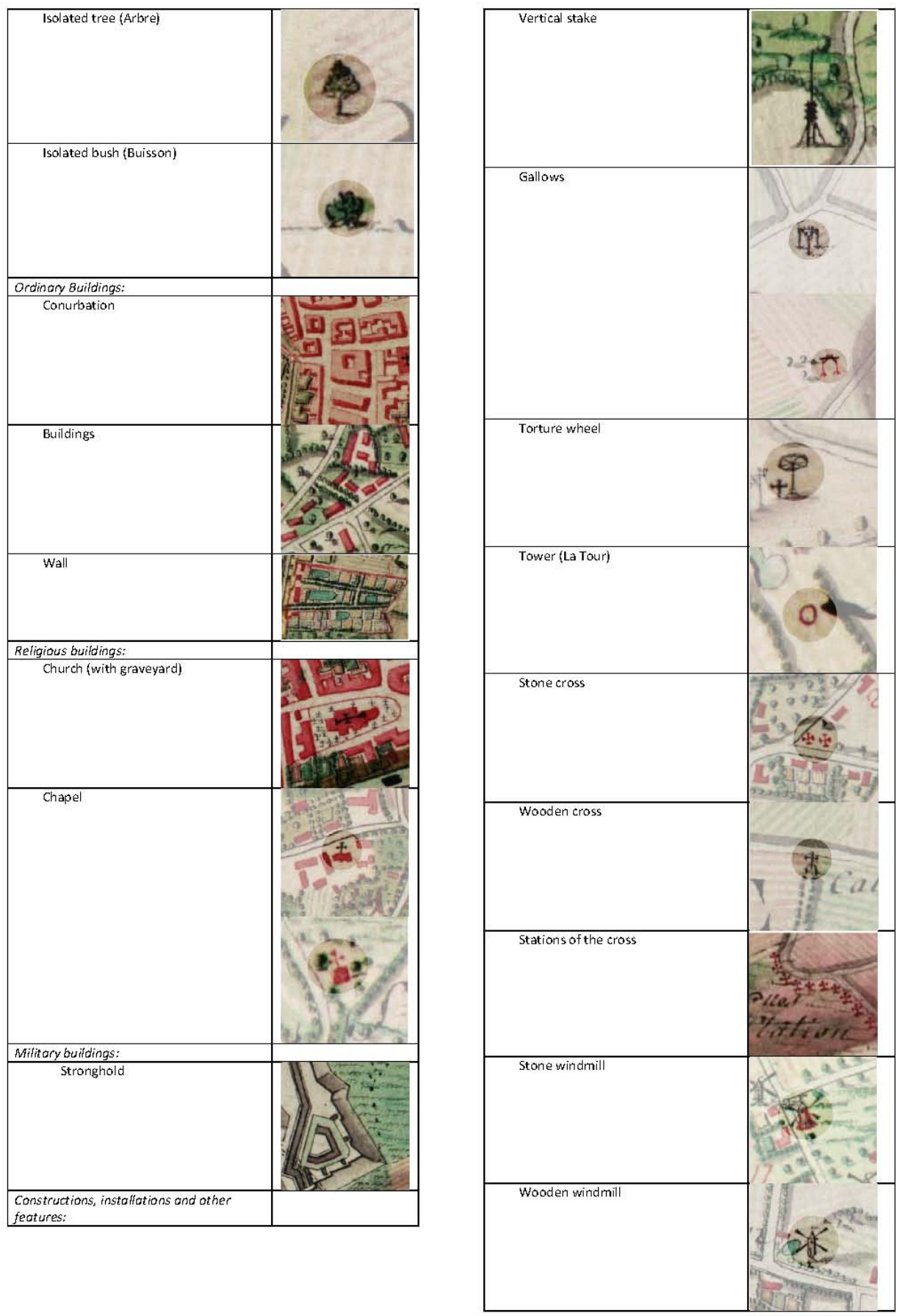


\begin{tabular}{|l|l|}
\hline Watermill \\
\hline Grave mount (Tombe) \\
\hline Mine (Mines- Houiliere) \\
\hline Quarry
\end{tabular}




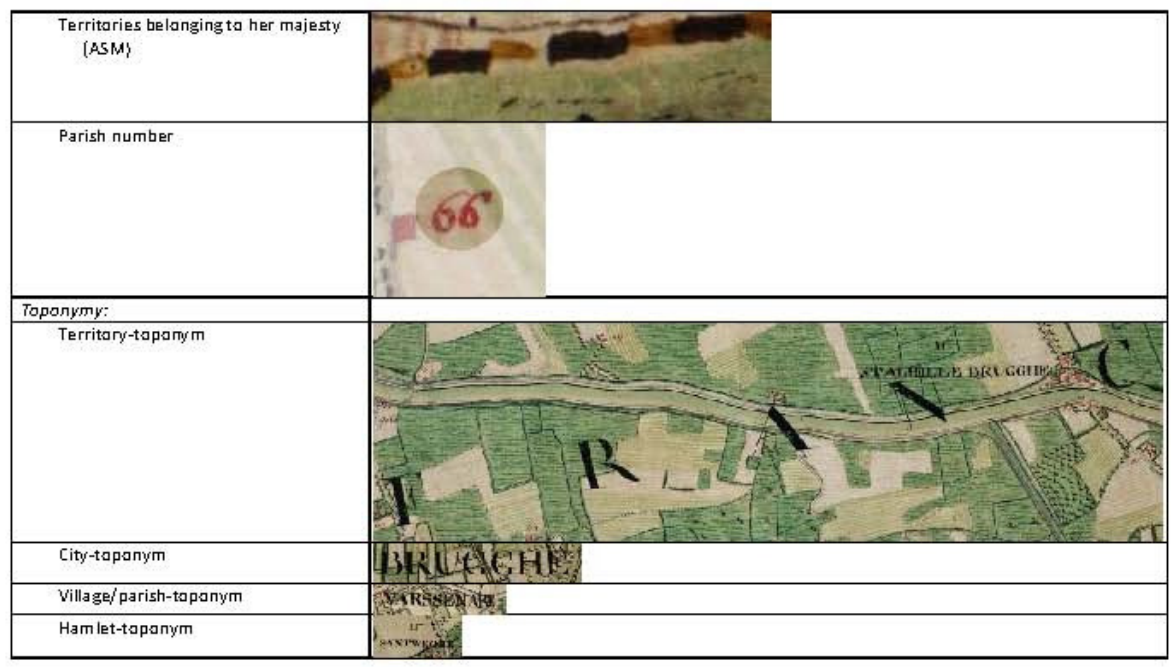

\begin{tabular}{|c|c|c|}
\hline Abbreviation & French term & Translation \\
\hline $\mathrm{C}^{25}$ & cense & Tenant farm \\
\hline $\mathrm{H}^{*}$ & fromeau & Hamlet \\
\hline Cha" & cróteau & Castle \\
\hline Abb. & abbaye & Abbey \\
\hline$c^{\mathbb{I E}}$ & chapelle & Chapel \\
\hline $\mathrm{Ch}^{\circ}$ & chemin & Road \\
\hline $8^{2}$ & \begin{tabular}{|l} 
bojs \\
\end{tabular} & \begin{tabular}{|l|} 
Farest \\
\end{tabular} \\
\hline$M^{\text {Cपr }}$ & mantagre & Hill \\
\hline
\end{tabular}

